\title{
Perceiving, explaining, and observing climatic changes: An historical case study of the "year without a summer" 1816
}

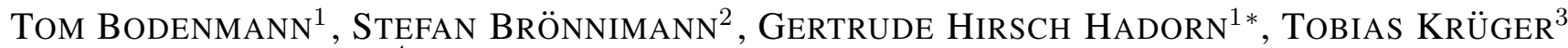 \\ and HELMUT WEISSERT ${ }^{4}$ \\ ${ }^{1}$ Institute for Environmental Decisions, ETH Zurich, Switzerland \\ ${ }^{2}$ Oeschger Centre for Climate Change Research and Institute of Geography, University of Bern, Switzerland \\ ${ }^{3}$ Staatsarchiv Solothurn, Solothurn, Switzerland \\ ${ }^{4}$ Geological Institute, ETH Zurich, Switzerland
}

(Manuscript received January 20, 2011; in revised form June 17, 2011; accepted August 9, 2011)

\begin{abstract}
The role of the "year without a summer" (YWAS) in 1816 in shaping the scientific discourse on climatic changes has been investigated in an interdisciplinary project by studying reactions of different knowledge systems to the YWAS as an initially unexplainable event. The analysis of two Swiss newspapers shows that contemporary science did not play a role in perceiving and dealing with the impacts of the YWAS on the population. Since no climate discipline of its own existed, few contemporary scientist, as we would call those men of science today, were ready to take this situation as an opportunity, reinforcing existing ideas in their domain (e.g. botany, geology, astronomy). Nevertheless, the YWAS did have impacts on science. A "call" was issued by the Swiss Natural Sciences Society shortly after the event. The work of one of the respondents became influential for the development of the ice age theory. By revealing a general lack of knowledge on climate, the YWAS might have contributed to the construction of meteorological stations at that time. Some contemporary scientists argued that the cold summer in western Europe was caused by huge masses of ice drifting in the North Atlantic. However, there were no theories that could have linked the exceptionally wet weather in Europe with a volcanic eruption on the other side of the globe. Not before the early $20^{\text {th }}$ century was the YWAS linked to the Tambora eruption of 1815. After almost two centuries, the YWAS has remained a challenge and source of inspiration.
\end{abstract}

\section{Zusammenfassung}

In einem interdisziplinären Projekt wurde der Frage nachgegangen, welche Rolle das „Jahr ohne Sommer" 1816 in der wissenschaftlichen Debatte über Klimawandel gespielt hat und weiterhin spielt. Die Wahrnehmung und der Umgang der Bevölkerung damals mit den Folgen des „Jahres ohne Sommer” war für die Wissenschaft nicht von Bedeutung, wie die Analyse der vollständigen Jahrgänge 1815-1817 von zwei Schweizer Zeitungen (NZZ, Schweizerfreund) ergeben hat. Da das Klima noch kein eigenes Forschungsgebiet war, interessierten sich nur wenige zeitgenössische Naturforscher dafür. Wenn, so wurde darin zumeist eine Bestätigung bestehender Auffassungen des jeweiligen Gebietes (Botanik, Geologie, Astronomie) gesehen. Trotzdem hatte das „Jahr ohne Sommer“ Einfluss auf die Wissenschaft. Die Allgemeine Schweizerische Gesellschaft für die gesammten Naturwissenschaften, Vorläuferorganisation der Schweizerischen Akademie der Naturwissenschaften, setzte ihre erste Preisaufgabe 1816 zu dieser Thematik aus. Eine der ausgezeichneten Antworten war für die Entwicklung der Eiszeittheorie von Bedeutung. Auch für die Errichtung meteorologischer Beobachtungsstationen dürfte das „Jahr ohne Sommer“ eine Rolle gespielt haben, da seitens der Gesellschaft beklagt wurde, dass meteorologische Daten generell fehlten. Einzelne zeitgenössische Wissenschaftler führten den kalten Sommer in Westeuropa auf grosse Eismengen zurück, die im Nordatlantik beobachtet worden waren. Hingegen fehlten Theorien, welche das ausserordentlich nasse Wetter in Europa mit der Eruption eines Vulkans auf der anderen Seite des Globus in Zusammenhang gebracht hätten. Erst im 20. Jahrhundert wurde das „Jahr ohne Sommer“ mit dem Ausbruch des Tambora 1815 verbunden. Nach beinahe zwei Jahrhunderten ist das „Jahr ohne Sommer“ eine Herausforderung und Inspirationsquelle für die Forschung geblieben.

\section{Introduction}

The year 1816 is known today in climate science as a "Year Without A Summer", with persistently cold and wet weather in eastern North America and in central and western Europe throughout the late spring and summer (e.g. BRIFFA and JONES, 1992; BRIFFA et

\footnotetext{
${ }^{*}$ Corresponding author: Gertrude Hirsch Hadorn, Institute for Environmental Decisions, ETH Zurich, CHN H 73.2, 8092 Zurich, Switzerland, e-mail: hirsch@env.ethz.ch
}

al., 1998; LUTERBACHER et al., 2004; TRIGO et al., 2009). The climatic anomalies were particularly large in Switzerland (PFISTER, 1999). The socio-economic impacts such as severe famine have been addressed in the historiographic literature (e.g. PFISTER, 1992). Also, the likely causes of the event have been studied in detail (e.g. SHINDELL et al., 2003). The eruption of Mt. Tambora in Indonesia in April 1815, cooled the Earth's surface through increased scattering of solar radiation at stratospheric sulphate aerosols. An additional (arguably 
small) contribution might have been related to decreased solar activity at that time known as the Dalton minimum. However, less is known on the role of the "Year Without a Summer" of 1816, hereafter YWAS, in the perception and explanation of climatic changes and in shaping the course of climate science. The YWAS was perceived by the population as a catastrophic event and deep-rooted religious and existential notions resurfaced, but the YWAS also posed a scientific challenge and an opportunity to promote new ideas or reinforce existing ideas. In Switzerland, the latter manifests itself in a competition (Preisaufgabe), a common funding scheme at that time, on the question of whether or not climate in the high Alps has deteriorated.

In this paper, we investigate the role of the YWAS in shaping the scientific discourse on climatic changes with a specific focus on Switzerland. The YWAS can be seen as an experiment of nature. Our goal is to study the reaction of different knowledge systems to the YWAS as an initially unexplainable event. For this purpose we distinguish perceived climatic change (how the YWAS was described in society), explained climatic change (whether and how the YWAS was explained by contemporary science, as well as basic differences to today's scientific explanations including modelled climatic change), and observed as well as reconstructed climatic change (whether and how the YWAS really was extreme, and its spatial pattern).

The YWAS posed a major scientific challenge at the time. We hypothesize that one of the reasons for that is the following: Fundamental changes in the scientific community, as we would call the social organization of science today, and the scientific understanding of climate had to take place before it was possible to arrive at today's scientific explanation of the YWAS as caused by the eruption of volcano Tambora in 1815 . We further look for pressure or expectations that may have been excerted on science from the government, private organizations, or the population, e.g. to provide an explanation of the disastrous event, to recommend measures in dealing with impacts, or to prevent further events of this kind. The background for these investigations is in science studies, which have provided major contributions to history of science (see for example SHAPIN, 2010). Our analysis is based on Fleck's theory of the "Genesis and Development of a Scientific Fact" (FLECK, 1979). According to Fleck, several factors are required to come to an explanation for an initially unexplainable event such as the YWAS, namely (1) a scientific community, which Fleck calls "thought collective". Members of this community (2) need scientific incentives for coping with the challenge. The issue has to be of scientific interest with regard to their research agenda. Coping with the challenge requires (3) that the scientific community is ready for further developing its epistemic means called "thought style" by Fleck. Basically this is about developing and mutually adapting concepts, theories and methods with findings to come up with an explanation for an initially unexplainable event as an inevitable fact. Last but not least, Fleck argues that (4) strong pressure from society on science is also necessary for scientists to take these efforts.

The paper is organised as follows. In section 2 we look at contemporary social incentives by analysing the reporting on the YWAS in two contemporary public periodicals which show how the YWAS was communicated to the population at that time and personal diary components. We then turn to contemporary science, starting with the competition of the Swiss Natural Sciences Society (Allgemeine Schweizerische Gesellschaft für die gesammten Naturwissenschaften; today: Swiss Academy of Sciences) and its context before giving an overview of the comments and ideas raised by men of science at that time regarding the YWAS, which we will call "scientists" although, according to the Oxford English Dictionary, this term was coined only some decades later. In section 3, following a few short comments on the scientific work carried out in the time linking the YWAS with the Tambora eruption, we turn to today's views on the YWAS and on the impact of volcanic eruptions on climate. In section 4 we conclude by summarizing and discussing the findings in the historical documents and the analysis of historical data with regard to our hypotheses.

\section{Contemporary views of the YWAS}

\subsection{Reporting on the YWAS in public periodicals and personal documents}

Two Swiss periodicals have been selected for analysis: the Neue Zürcher Zeitung (NZZ), and the Schweizerfreund. The NZZ, which still exists today, was founded in 1780 by Salomon Gessner, who was also the editor and a partner of the newspaper's publisher (Orell, Gessner \& Co.) and a politically engaged promoter of enlightenment thinking. In the years around 1816, Johann Heinrich Füssli was editor of the NZZ and main partner of its publisher Orell, Gessner, Füssli \& Co. He was a strong promoter of democratic ideas, had acted as a professor for national history at a Zurich College, and as minister of the Helvetic Republic, but had to quit with the end of the Helvetic Republic. For political reasons, the NZZ focused on news from abroad and factual reports (MAISSEN, 2005, page 21-28). The newspaper had four pages and appeared twice a week, with a supplement from time to time. The Schweizerfreund (SF) existed from 1814 to 1829 as a journal for the Swiss population and covered a broad range of topics of interest in everyday life. The periodical had eight pages and appeared once a week. It was associated with the Bernese government during the restoration period. The two periodicals addressed complementary sectors of the population, but were equal in size, and both were easily accessible.

We analysed the content of all newspaper editions in 1815,1816 , and 1817 regarding reports on weather, climate, and natural hazards (comprising ten subcategories 
like rain, drought, floodings, temperature etc.), on socioeconomic impacts (six subcategories such as impacts on agriculture, infrastructure, population etc.), and on policies and measures (comprizing 14 subcategories, including measures by the administration, the church, and others). By reading through all newspaper editions, text passages referring to those subcategories were coded accordingly. Frequencies of subcategories were calculated, counting a subcategory only once in cases it occurred several times in the same newspaper edition, and statistically analysed. In total, 962 reports (coded text passages) were counted. The Schweizerfreund reported four times more frequently $(79 \%)$ than the NZZ (21\%). While the bulk of NZZ's reporting is in $1816(77 \%)$, with few reports in $1815(6 \%)$ and again in $1817(17 \%)$, the Schweizerfreund reported even more frequently in $1817(54 \%)$ than in 1816 (43\%), and less so in 1815 $(4 \%)$. These differences are statistically significant $\left(X^{2}\right.$ test for homogeneity: $X^{2}=87.92$, critical value of $\left.X_{a=0.05, d f=2}^{2}=5.99\right)$. In total, reports on weather, climate and natural hazards (35\%) were as frequent as on socio-economic impacts (36\%), while policies and measures were reported slightly less frequently (29\%). The NZZ gave slightly more emphasis to socio-economic impacts, while in the Schweizerfreund weather, climate and natural hazards $(37 \%)$ were more frequently reported. The results of this quantitative analysis show that the YWAS was a real issue in the public newspapers at that time. Differences in frequencies found between the two periodicals can be explained by the background and context of the periodical and the target audience (i.e. the focus on political news versus a broad range of topics of interest in everyday life).

Coverage in reporting was mostly regional, but also included neighbouring countries and sometimes reports from Northern America and coastal communities on the North Atlantic. Within these reports on weather, climate, and natural hazards we find more frequent mentioning of properties related to the hydrological cycle, encompassing precipitation (rain, snow, fog), thunderstorms and storms (wind, lightning, thunder, tornados, hail) as well as flooding, landslides, and avalanches, as compared to thermal properties (heat, cooling, frost). It is interesting to note that instrumental observations were rarely mentioned. More relevant were weather observations, or simply sensory perception. A further interesting finding is that explanations were mentioned very rarely. Besides perceiving the YWAS as sent by God, several explanations with a scientific basis were reported, although they were generally portrayed as unconvincing: sun spots, the installing of lightning rods, a changing of the position of the sun in the solar system, or comets. It is mentioned that other regions had different weather conditions to those in Central Europe: dry weather for instance in Russia and Sweden during August 1816 (SF 20 Aug 1816, page 283).

Policies and measures that are reported do not relate to such explanations with a scientific basis but include church services, food supply, market interventions and regulations, prohibition of wasting of food, and advice on how to process low-quality food, community work, and charity. The focus of concern at the time included rising prices for agricultural products, shortage of food, famine, and misery. A quote from a farmer's and local magistrate's unpublished diary (Johann Peter Hoffmann 1753-1842) living in Alsace close to Switzerland, which was sent to us during the course of the project, illustrates this conclusion from the media analysis:

"On the $6^{\text {th }}$ of July I was in Pfalzburg. Yesterday wheat was $23 \mathrm{f}$ per Frl, a loaf of bread costs $27 \mathrm{~S}$. The rainy weather continues. The hay has not been made anywhere. The grass is rotting on the meadows, all mountains are full of water. There is nothing but misery everywhere. The beggars are so frequent that there is no council, the poor suffer a lot. Potatoes can almost not be found. The sester costs 30 to $34 \mathrm{~S}$ and are hard to get. Nothing can grow, it is always too cold, I do not know what will happen until harvest which will be very late. Fortunately, as to what concerns ourselves, there is no paucity." ("D. 6 ten July bin ich zu Pfalzburg geweßen. Der Weizen hatte gestern bis $23 \mathrm{f}$ das Frl gegolten, der Laib brod kostet 27 S. Das Regenwetter hält noch immer an. Es ist noch nirgends kein Heu gemacht. Das Graß in den Matten fault, alle berge halten voll Waßer. Es ist nichts als Elend überall. Die bettler kommen so häufig, daß kein rath zu thun ist, der arme muß sehr noth leiden. Grundbirn sind fast nirgends keine mehr. Der Sester gild 30 bis $34 \mathrm{~S}$ und sind nicht zu bekommen. Es kan nichts wachsen, es ist immer zu kalt, ich weis nicht was es noch geben wird bis Ernde die sehr spät kommen wird. Gottlob, was uns anbetrifft, wir haben kein Mangel.") (Hoffmann, entry on 16th July 1816, II, page 58)

The diary contains detailed information on the development of prices for farm products at local markets during that period, as for instance the price for potatoes at a local market rising from 6 Francs/sester in March 1816 to $18-20$ Francs/sester a year later. Also, texts written in memory of the suffering during that period (Erinnerungsblätter), which were popular among the population (TANNER, 2004), documented the rising and falling of prices for agricultural products.

Long term mitigation measures against famine that were taken after 1816 include means such as improvements in agricultural production and prevention against flooding (TANNER, 2004).

In sum, the content analysis of the two periodicals indicates that contemporary science did not play a role in understanding and dealing with the impacts of the YWAS although some ideas on the YWAS by contemporary scientists from various fields of expertise have been reported. In addition, we did not find indications for social incentives such as expectations or pressure from the population, the government or private institutions to provide a scientific understanding of the YWAS. Regarding incentives within science, explaining the YWAS as a climatic fact seemed to be a great challenge. This is man- 
ifest in the competition question of the Swiss Natural Sciences Society in 1817 , which was also published in the NZZ (17 Oct 1817, page 1) and the Schweizerfreund (14 Oct 1817, page 346), among other media.

\subsection{The Swiss Natural Sciences Society's competition}

In 1816, members of the Swiss Natural Sciences Society proposed 13 topics for the society's first call as a "prize question" or "competition", which was a common research funding scheme. One of the questions was the following: "Is it true that our higher alpine regions have been turning into wilderness during the last few years? What are the causes of this and how could one take preventive measures?" ("Ist die Thatsache gegründet, dass unsere höheren Alpen seit einer Reihe von Jahren verwildern? Was sind die Ursachen davon, und wie könnte ihnen vorgebogen werden?") (USTERI, 1817, page 16). In 1817, the society's Central-Commission took its decision on this topic.

On the one hand, this can also be seen as reinforcing pre-existing positions. In 1781, the Bernese "Economic Society" (Oekonomische Gesellschaft), most probably initiated by Samuel Wyttenbach, launched a similar question: "Can it [...] be proven to us that through the progress of our ice mountains [...] a lot of land formerly usable as pasture now lies covered by ice mountains or [...] on higher alps feral or lost by chance." ("Kan uns [...] bewiesen werden, dass sowohl durch den fortgang unserer Eisgebirgen [...] vieles zum Weidgang ehmals brauchbares Land gegenwärtig entweder durch Eisgebirge bedeckt liege, oder [...] auf den höheren Alpen erwilderet, oder durch Zufälle verlernt worden.”) Quoted in KRÜGER (2008, page 72). It found no participants. However, as Tobias Krüger (KRÜGER, 2008) suggests, it seems that Friedrich Kuhn intended to answer the question in his seminal work on glaciers 1786 (KUHN, 1787). Among other things, Kuhn voiced the idea that glaciers give evidence of past climatic variations. In the same year, Samuel Wyttenbach founded the "Private Society of Friends of Natural Scientists in Berne" (Privatgesellschaft naturforschender Freunde in Bern). When the Swiss Natural Sciences Society discussed its competition, the meeting took place in Bern and Samuel Wyttenbach presided.

On the other hand, in justifying its choice for this topic, the Central-Commission noted among other reasons that very recent events would give special importance to this topic.

The commission formulated the call of its first competition in October 1817 without the second and the third question of the original proposal. The commission argued that including questions concerning causes and preventing measures would run the risk of biases in investigation because answers concerning causes or preventive measures assume that a cooling has taken place which has to be proven first. In addition, finding evidence for cooling would already be a substantial amount of work "because direct evidence from instrumental observations for a series of years are missing." ("Da es an direkten Beweisen hiefür aus vieljährigen thermometrischen Beobachtungen fehlt.") (USTERI, 1817, page 17) Interestingly, Marc-Auguste Pictet, a leading meteorologist of that time, was among the members of the Prize-Commission (SIEGFRIED, 1865, page 14). The commission specified its question by explicitly asking for "testimonies and indicators on the abandonment and degradation of former alpine pastures" ("eine umfassende und möglichst vollständige Zusammenstellung aller der ältern und neuern Zeugnisse, welche für die Verödung und Verlassung der ehemaligen Weidplätze in den Hochalpen aufzufinden sind") (USTERI, 1817, page 18). Thus they also emphasised distinguishing cases of causes for degradation other than temperature. Further evidence the commission asked for was on the limits of snow and on the glacier extent. In essence, the competition focused on evidence for cooling in the alpine region during recent years.

The competition received a lot of attention, even Johann Wolfgang von Goethe was interested and wanted to be informed (GOETHE, 1970, page 213). However, probably due to the short timeline, there was only one contribution sent to the commission in time. The contribution came from Karl Kasthofer, Head Forester of the Bernese Oberland, a scientist well respected by his peers. Most importantly, he was in the position to provide the documentation that was requested, but only for the limited region of the Oberland. Kasthofer focused on land use changes in the high Alps and the political liberal forester identified the market as the driving force of land use changes. Once land use had changed, local climate change might follow. Because of the limited scope of his paper, Kasthofer received the second prize and the call was left open. In this second round there were two respondents, but only one was regarded worth considering by the Prize-Commission. Its author, Ignatz Venetz, received the prize. Venetz, chief engineer of the canton of Valais, looked at glaciers as an indicator of climate change. He found that the response of glaciers to temperature variations did vary locally, but that there was evidence for a recent cooler period which was coming to an end (KRÜGER, 2008, page 132). His paper was published in re-written form several years later (VENETZ, 1833). Importantly, Venetz also found evidence for much larger glaciers much further back in time and reported his findings on alpine glaciation to the Swiss Natural Sciences Society in 1829 (VENETZ, 1830, page 31). Venetz's work became influential for the development of the ice-age theory.

The reactions of scientists to the Swiss Natural Sciences Society's competition support Fleck's thesis on the role of the scientific community and scientific incentives for addressing initially unexplainable events. Since no scientific community on weather and climate existed, the winners of the prize looked at the problem of alpine degradation from the perspective of their field. Forester Karl Kasthofer discussed the problem in the 
context of changing land use due to market forces taking up the idea of climate reacting to land use changes dating back to antiquity (FLEMING, 1998). Engineer Ignaz Venetz focused on glacier dynamics, on which he had already published a paper in 1816. At that time, what we would consider as climatology was not a field of its own but rather a topic within the fields of botany and geology. Consequently, the respondents to the prize question came from these communities and reacted to scientific incentives in their fields. Interestingly, meteorology was quite explicitly excluded from the prize question (BRÖNNIMANN, 1999).

\subsection{Contemporary scientific views}

The "competition" of the Swiss Natural Sciences Society may have been triggered, among many other factors, by the perception of the YWAS, and it may have had a considerable effect on science over the long term. However, the contributions to the "competition" did not address the YWAS explicitly. In the following, we present the results of our study of comments found in the general science literature on the YWAS of 1816. The following sources have been screened regarding scientific publications concerning the YWAS: Bibliothèque britannique/universelle, Göttingische gelehrte Anzeigen, Annalen der Physik (Gilbert's Annalen), and Philosophical Transactions of the Royal Society of London, among others. It was found that only very few contemporary scientists commented on the YWAS and no convincing explanation was found. Although the eruption of Tambora was known at the time (EAST INDIA COMPANY, 1816a, b; PICTET, 1817), no contemporary scientist (known to us) made the connection with the YWAS.

One line of thinking linked the YWAS with drifting sea ice, an idea that has to be seen in the longstanding ambition to find a Northwest Passage. In 1817, the British Royal Society used significant resources to investigate the claim that the arctic sea ice was abating. President of the Royal Society Joseph Banks wrote: “ (...) a considerable change of climate, inexplicable at present to us, must have taken place in the Circumpolar Regions, by which the severity of the cold that has for centuries past enclosed the seas in the high northern latitudes in an impenetrable barrier of ice has been during the last two years, greatly abated." (BANKS, 1817, page 150). In the same year, explorer William Scoresby observed that "2000 square leagues (18 000 square miles) of ice with which the Greenland Seas between the latitudes of $74^{\circ}$ and $80^{\circ} \mathrm{N}$ have been hitherto covered, has in the last two years entirely disappeared." (BANKS, 1817, cited by JACKSON 2009, page xxix) In 1818, the English Admiralty sent four ships to further explore the Arctic Sea. Secretary to the Admiralty of Great Britain John BARROW (1819, page 162) mentioned enormous ice fields, which must have broken loose from Greenland after 1815, as one of the reasons for the expedition, and the hope for an open Northwest Passage. For Barrow, there was no doubt that the drifting polar ice caused the
YWAS in Great Britain and North America (BARROW, 1819, page 164/166).

German physicist and astronomer Ernst CHLADNI (1819, page 132-133) maintained a similar idea. In Chladni's theory, the melting of the ice filled the air with moist exhalations and deprived it largely of its heat ("Wärmestoff"). The large amount of ice floes in the Gulf Stream caused a constant west wind, which brought the cold and wet air to Western Europe. Chladni saw his theory confirmed by the fact that countries located outside this airflow (such as Sweden, Northern Poland or Russia) reported dry and warm conditions. Consequently, he did not understand the YWAS as a global phenomenon. He substantiated his theory by pointing out other years $(1776,1777,1802)$, where excessive amounts of sea ice or persistent winds coincided with extraordinary weather events. By making reference to the banded appearance of other planets (which he interpreted as persistent zones of bad weather), he emphasised the universal character of such events. Chladni based his assessments on reports from fishermen and foreign papers.

The idea that the YWAS was linked to sea ice was also discussed by GAY-LUSSAC and ARAGO (1817, page 437-438). The authors referred to whalers that reported the disappearance of large ice fields near Greenland in 1816 and reports of large floes of ice close to the tropics. However, the authors thought it was not justified to draw any conclusions because other cold years (1805) did not show a correlation to sea ice. Modern research confirms that the summer of 1816 (following the Tambora eruption) was unusually warm in the Greenland Sea, as was the following summer (BROHAN et al., 2010, page 38). Ships sailing to Halifax and Newfoundland in 1815-17 reported sightings of "ice islands" as far south as the 40th parallel (BROHAN et al., 2010, page 39). In the same period, whaling ships in the Davis Strait reported an unusual number of icebergs and floes drifting southward (BROHAN et al., 2010, page 40).

Contemporary German physicist and meteorologist $\mathrm{H}$. W. Brandes acknowledged the strange character of the summer 1816 as well (BRANDES, 1817, page 112). He collected weather reports from all over the world and remarked that some countries seemed to have exceptionally cold weather while others experienced dry and hot conditions. Brandes lamented that he was not able to deduce any significant results because of a lack of meteorological data. He argued for more weather stations and the need for weather charts. In 1820, Brandes published the first weather charts and is therefore considered the founder of synoptic meteorology.

Marc-Auguste Pictet, physicist, meteorologist, and astronomer from Geneva explained the YWAS by an anomalous distribution of heat and precipitation over Europe during the summer of 1816 ("un défaut dans l'équilibre ordinaire de la distribution de la température sur le continent d'Europe") (PICTET, 1816, page 186). While Central Europe had to endure cold and wet weather, Russia and the Atlantic Ocean suffered from 
exceptional dry and hot conditions, hence other countries received what Europe was missing. Rather than investigating the causes of the bad weather, Pictet focused on refuting the alleged connection between sunspots and the cold weather (an opinion which was popular in the public media). He noted an accidental coincidence ("coincidence fortuit") between a cold and rainy season ("une saison remarquablement froide et pluvieuse") and the appearance of some sun sports ("l'apparition de quelques taches au soleil") (PICTET, 1816, page 186). Pictet added several reasons for his assessment such as the non-correlation between sunspots and climate in earlier years and the non-global character of the YWAS (in his view the YWAS was limited to Europe). Pictet added that sunspots covering only about $1 / 1000$ of the sun's surface cannot have a significant effect on earth's climate.

British astronomer W.M. Moseley agreed with Pictet that sunspots could not explain the cold weather of 1816. Moseley gave the following four arguments: Sun spots were not extraordinary large in 1816, the area covered by spots was too small to hold off relevant quantities of light, the lifetime of sunspots was too short to have a relevant effect, only $1 / 4$ of the globe experienced cold weather, but sun spots would act global (MOSELEY, 1818, page 413-414). Interestingly, there was a reaction on Moseley's publication by C.B. Mollweide, a mathematician and astronomer from Halle, Germany. However, Mollweide did not comment on the YWAS at all but talked about how to correctly calculate the path of sunspots on the suns surface (MOLLWEIDE, 1818).

In another instance, PICTET (1818, page 94) noted that the 5-year-mean-temperatures of the observations so far published (22 years) seem to support cooling climate theories but he did not comment further on it. He also did not relate this result with the YWAS. The explanation of the YWAS took only a secondary role in his paper - this is somewhat disturbing, since in general, Pictet showed great interest in meteorology. Either scientists like Pictet did not perceive the YWAS as something that was in need of a broader scientific assessment or they were simply unable to provide a more detailed explanation. The YWAS and the prize question with its focus on the high Alps may be a reason that Pictet erected a weather station in 1817 at the Gr. St. Bernhard at $2400 \mathrm{~m}$ asl. However, in a letter describing the station, the recent events of the YWAS were not explicitly mentioned. Rather, Pictet was referring to a general lack of knowledge on the atmosphere at high altitudes.

Furthermore, existing theories about the nature of sunspots were not compatible with the alleged cooling effect (PICTET, 1816). Eynard (cited by PICTET, 1816) remarks, that no plausible theory about sun spots is coherent with a decrease of sunlight. Niles weekly register (NILES, 1816, page 385-386), one of the most widely circulated magazines in the United States, reported: "We think the alternation [of climate] took place before the spots were observed, and that possibly it was produced by the late earthquakes." STOMMEL and STOMMEL (1983) give some more insight on this line of thought. It was believed that earthquakes of 1815 had interrupted electrical fluids circulating beneath the surface, which led to cooling by reducing the interior resistive heating. Stommel and Stommel write that lightning rods were thought to be responsible for causing the YWAS not only by the public but also by a learned scholar at Milan Observatory in Italy. An article in "Annalen der Physik" gives some possible context for this. Some held that clouds are condensed by electricity. The more electricity in air the sooner it would rain. Lightning rods would discharge air, which would result not in thunderstorms but in very long lasting rainfalls (GÜTLE, 1820).

The YWAS experienced very little immediate scientific resonance. Scientists were aware of the YWAS, but felt unable to even look for an explanation (see also BRÖNNIMANN, 2002). Since no discipline of its own on climate had yet been established, there was no scientific conception of climate. As the winners of the Swiss Natural Sciences Society's prize, contemporary scientists looked at the YWAS from the perspective of their specific domain. Astronomy was a popular field at the time, hence the prominent comments on sunspots. Explorers hoped for an opening of the Northwest Passage and connected the YWAS with the movement and disappearance of polar sea ice, a theory that received some support from physicists like Chladni. Scientists more closely concerned with weather phenomena like Pictet and Brandes noted the strange character of the weather but neither had enough data nor reasonable theories to explain the strange, regionally different conditions. At most, hypotheses included, in a very general sense, topics that were discussed in contemporary science such as electricity. The role of scientists was rather to oppose amateur theories.

At first glance, the lack of scientific resonance for the YWAS at the time is surprising since climate change was clearly an issue around 1816, at the climax of an exceptionally cold decade. For example GAY-LUSSAC and ARAGO (1817) reported that the slightly warmer temperatures in 1817 fuelled hopes for a climate warming. They also mention reports on the ceased wine production in Great Britain and the abandonment of colonies in Greenland as indicators for climate cooling, as does BARROW (1819). Niles (1816) and PICTET (1818) report evidence for a cooling climate. A variety of factors, among them volcanoes, were considered climate relevant at the time: "[...] an infinity of circumstances, such as winds, volcanoes, the proximity to the sea, the position of mountains, combine with the influence of the sun, and often make the temperature very different in two places situated under the same parallel." (D'AlEMBERT, 1753). Benjamin Franklin made a connection between volcanoes and colder weather in 1783 (FRANKLIN, 1785). Since the eruption of Tambora was reported in the Bibliothèque universelle in 1817, one would not anticipate the complete absence of any link 
between the volcanic eruption and the YWAS in contemporary science.

The picture gets more coherent if we look at the state of the fields of climatology and meteorology (in the sense of atmospheric physics) at the time from the perspective of Fleck's theory and today's state of knowledge, showing the need for considerable efforts in developing epistemic means such as concepts, theories, and methods. Jean Le Rond d'Alembert distinguished two types of "climates" termed "real climates" and "apparent climates" in his entry on "climate" in the "Encyclopédie des sciences" (D'AlEMBERT, 1753). He noted that the term "climate" is commonly used to denote a portion or zone of the surface of the earth, while "apparent climates" is given to a land regarding seasons, qualities of soil, or even people who live there. At the time, meteorology was the science of meteors and weather phenomena were in part related with nitrous and sulphurous vapours, which in turn were also related with earthquakes (JANKOVIC, 2006). Quantified measurements of temperature, pressure, and humidity were overshadowed by descriptive reports of extreme occurrences. In his speech at the presentation of the prize question USTERI (1817) stated that meteorology had a considerable reputation problem because understanding and forecasting the weather was the domain of astrology and superstition.

By 1800, the exploration of the atmosphere slowly got on track. Meteorology started to be associated with the atmosphere as a laboratory of chemical and electrical processes. It changed from science of meteors to a theory of atmosphere and weather forecasting. Electrical fluid became an explanatory concept. Synchronization, standardization, and quantification became more important issues but were still insufficient (JANKOVIC, 2006). Around 1816, the consensual picture of meteorology was profoundly different from other sciences and considered to be in its earliest infancy. New meteorologists had nothing to build upon. Observations were too few and inaccurate to form a meteorological theory, and there was a paralyzing lack of information and theory (JANKOVIC, 2006, page 97). Evaporation was recognized in the 19th century as an important process affecting the water cycle (e.g., measurements by Pictet). It was linked with land use, climate, and "exhalations". Climate factors such as deforestation or volcanoes were typically assumed to affect climate on a local or regional level. The reports show that the YWAS was perceived as a regional anomaly. There was no sufficiently standardized and developed network of weather stations. The occasional reports on weather conditions in North America or Russia were not sufficient to obtain a hemispheric of global view of climatic variations. There was not even a sufficiently standardized and developed network of weather stations to systematically observe regional variations. One has also to consider that the YWAS was perceived as an extremely wet event. The heavy precipitation was probably more in need of an explanation than the cold temperatures. But theories that could have linked the exceptionally wet weather in Europe with a volcanic eruption on the other side of the globe were missing. We conclude that climate was not conceived as a global system.

\section{The YWAS in science history and current views}

\subsection{The YWAS seen as a consequence of the Tambora eruption}

In this section, a review of the history of how the YWAS has affected the scientific discussion on climatic changes between 1816 and now is given. We focus on its relation to the Tambora eruption, although the YWAS was also discussed in the context of other causes such as low solar activity (Dalton minimum). For further details on the following, the reader is referred to the papers by DöRRIES (2006) and SCHALLER et al. (2009).

According to the literature and our own research, the YWAS was not linked to the eruption of Tambora until the early $20^{\text {th }}$ century. After the eruption of Krakatau in 1883, Tambora was often cited as an historical precedent but mainly with respect to volcanological properties. In fact, the extensive report that was commissioned by the Royal Society after the Krakatau eruption (SYMONS, 1888), although providing detailed information on atmospheric effects such as sightings of the ash clouds, special optical phenomena, and shock waves, did not address climate as such. Nevertheless, the eruption of Krakatau was perceived as an event with global effects. This led to changes in the explanation of the effects that volcanic activities could have on climate. In 1888, Italian geologist T. Taramello advanced the idea, probably for the first time, that volcanic eruptions might have an influence on global climate (TARAMELLO, 1888). In 1893, his compatriot L. De Marchi published an extensive paper in which he explicitly referred to Krakatau and came to the conclusion that volcanic eruptions were the most likely triggers for ice ages (DE MARCHI, 1895). Obviously without knowing his considerations, the cousins F. and P. Sarasin advocated a similar thesis. After a joint journey to Indonesia, they published a paper mentioning, among other volcanoes, Krakatau and argued for a causal link between volcano eruptions and ice ages (SARASIN and SARASIN, 1902).

It was only after the next two big eruptions, Santa Maria (1902) and Katmai (1912) that the link between the YWAS and the Tambora eruption was made. Three drivers of this discussion are worth mentioning: (1) the recent eruptions, (2) the emergence of research on solar radiation, and (3) the vivid discussion on ice age theories. Time series of radiation measurements, reaching as far back as 1883 (prior to Krakatau), showed that volcanic eruptions lead to decreases of the incoming solar radiation (АввотT and FOWLE, 1913; see DöRRIES, 2006, for more details). The explicit link between Tambora and the YWAS was then drawn by HUMPHREYS 
(1913, page 161). By that time, he was a strong proponent of the thesis that ice ages were initiated by volcanic dust (Fleming, 2007, page 69). Humphreys referred to the publication by the two Sarasins (HUMPHREYS, 1913, page 137). As a professional meteorologist, he was especially interested in the scattering and absorption effects of volcanic aerosols and in the importance of aerosol size for these properties.

In the subsequent decades, the effect of volcanic eruptions on climate was further refined, and indirect effects (via circulation changes) were invoked (DEFANT, 1924), albeit not specifically with reference to the YWAS. At the same time, the meteorological conditions during the YWAS were studied quantitatively (Milham, 1924). The interest in historical volcanic eruptions then strengthened in the 1960s in the context of discussions of effects of nuclear bomb tests and atmospheric dust on climate (see DöRRIES, 2006). At this stage, historical climatology, pioneered by Hubert H. Lamb (LAMB, 1970) provided information on past eruptions, including Tambora, that could be used statistically.

Renewed interest in the YWAS and its relation to Tambora emerged following the papers by ALVAREZ et al. (1980) on the asteroid hypothesis for the CretaceousTertiary extinction as well as the discussion on the nuclear winter (CRUTZEN and BIRKS, 1982; TURCO et al., 1983) and the eruption of El Chichón in Mexico in March 1982. Discussion evolved around the scientific topics of terrestrial catastrophies, aerosol microphysics, and stratospheric transport. In this context the YWAS became interesting as an analogue. The classic YWAS papers by STOMMEL and STOMMEL (1983) and STOTHERS (1984) fall into this period.

\subsection{Current views}

Almost 200 years after the eruption of Tambora, the YWAS still plays a role in climate science, as is evidenced by the considerable number of research papers and presentations at scientific conferences. This paper is such an example. There are at least four reasons for this. Firstly, the YWAS is perceived as "worst case" at the scale of interannual variability. In the research area of interannual climate variability, predictability has become an important topic in the recent discussion. Strong eruptions will undoubtedly also occur in the future. The better we understand the effect of explosive tropical eruptions, the better we will be able to predict climate over the years following an eruption. The YWAS followed the strongest eruption and shows the strongest effect in the instrumental climate history and hence draws attention.

Secondly, the YWAS as an extreme event may help to understand natural climate variability in general (see SHINDELL et al., 2003) and variability in other climate records and climate proxy archives specifically. This thread is not new, but keeps raising interest in the YWAS as more and more records become available.
Thirdly, volcanic effects on climate are related to stratosphere-troposphere coupling (ROBOCK, 2000), and the dynamics of the mechanisms of stratosphere-troposphere coupling have received a lot of interest in recent years (BALDWIN and DUNKERTON, 2001).

Fourthly, the ongoing discussion on climate engineering also triggers new interest in historical eruptions. It has recently been suggested to inject sulphur into the stratosphere to counteract global warming (CRUTZEN, 2006). Similar to a volcanic eruption, this might lead to a cooling of the globe. Once again, this puts the spotlight on the microphysical processes and their importance in determining the climatic effects.

In all cases, the continued interest in the YWAS is also related to its timing at the change-over from the "proxy period" to the early instrumental period. This period becomes more and more accessible for scientific studies due to large efforts in compiling proxies, digitizing historical data, and efforts in constraining model simulations for historical times. Hence, despite the many studies that have already been performed on the YWAS, the "knowledge increment" is still large for the YWAS in the current situation as the amount of information as well as the methods are improving particularly rapidly.

Concerning the processes, it is now assumed that the effect of volcanoes on climate occurs almost exclusively through stratospheric sulphate aerosols (see ROBOCK, 2000 , for details on the following). They scatter incoming solar radiation (thus increasing the albedo and decreasing the amount of solar radiation reaching the surface; a cooling effect). The forward scattered light increases the proportion of diffuse radiation, which may be important for plant life. In addition, the particles absorb near infrared and infrared radiation both from the sun and from the earth. The absorption heats up the stratosphere. The heating is not uniform due to the non-uniform distribution of the aerosols layer and of both solar and terrestrial near-infrared radiation. Differential heating follows, which enhances the stratospheric westerly circulation in the respective winter hemisphere. Through downward propagation, this change can affect climate near the ground. The aerosols further affect the formation of cirrus clouds and stratospheric ozone chemistry. Moreover, other gaseous emissions from volcanic eruptions might alter stratospheric chemistry.

Climate is thus affected directly by the reduction of incoming short-wave radiation and indirectly via changes in the stratosphere. The size of the aerosols controls the ratio of scattering versus absorption, and this may depend on the type and magnitude of the eruption.

Volcanism today is recognized as an important climate forcing factor in earth's history (e.g. SVENSEN et al., 2009). In contrast to the Tambora eruption, volcanic megaprovinces which erupted in the geological past resulted in extreme $\mathrm{CO}_{2}$ pulses and, sometimes, in main extinction events. Comparison of volcanic outbursts in earth's history with historical eruptions is of increasing interest for the scientific community. New geochemical techniques used in earth's history provide detailed in- 
formation on changing atmospheric chemistry and climate over hundreds or thousands of years (e.g. MÉHAY et al., 2009). Whether extreme greenhouse pulses related to massive volcanism in earth's history were preceded by short cooling episodes is part of an ongoing scientific debate.

Within other parts of this project, some of these science issues (e.g. the role of the aerosol size distribution for the radiative effects of the Tambora eruption or the amount of YWAS cooling in Switzerland attributable to circulation changes and clouds) were addressed and will be published in subsequent papers.

\section{Conclusions}

In order to investigate reactions of different knowledge systems to the YWAS as an initially unexplainable event we analysed how the YWAS was perceived in society, whether and how the YWAS was explained by contemporary scientists, as well as basic differences to today's scientific explanations (including modelling). Furthermore, research questions have been framed by considerations from science studies (FLECK, 1979), stating that developing and mutually adapting concepts, theories, and methods with findings is required to turn an initially unexplainable event into a scientific fact. To be able to undertake efforts of this kind, researchers need to form a scientific community providing scientific incentives and they need social incentives directing resources onto tackling the challenge. Our investigation of the YWAS in science has shown, that none of the four conditions were fulfilled at that period.

Regarding social incentives for scientific efforts, one of Fleck's four conditions, we investigated perceived climatic change. Results of the analysis of the two public newspapers show that reporting on weather, climate, and natural hazards, on socio-economic impacts as well as on policies and measures was exceptionally frequent, highlighting their extraordinary and catastrophic character, especially properties related to the hydrological cycle. Explanations, including very few ideas on the YWAS by contemporary scientists from various fields of expertise, were mentioned very rarely. Society did not ask for explanations of this event in addressing the sufferings of the population, which was a focus of concern. We conclude from these findings that contemporary science did not play a role in how the population perceived the YWAS and was dealing with its impacts. We found no indications for social incentives for scientists to strive for an explanation of YWAS. Since the extraordinary weather in the YWAS was not perceived as anthropogenic (besides the religious interpretation and the hypothesis concerning lightning rods), the cause of this variability was not an ethical issue.

Explaining the YWAS as a climatic fact seemed to be a great challenge. No scientific community of its own dealing with the topic of climate variations, which is Fleck's first condition, existed, and astronomers, physicists, chemists, botanist, meteorologists (labelled as "weather prophets") were the only scientists at the time able to tackle the problem. Although the state of knowledge at the time did not allow for conclusive explanations, efforts to develop and mutually adapt concepts, theories and methods with findings, which is another condition put forward by Fleck, were missing. From today's state of knowledge, the main reasons for the lack of conclusive explanations are the following. Climate was conceived as regionally determined and - in principle - stable, thus giving rise for instance to explaining the YWAS by compensating hot and dry weather elsewhere. Climate factors such as deforestation or volcanoes were typically assumed to affect climate on a local or regional level. The reports show that the YWAS was perceived as a regional anomaly. The idea of climate as a globally complex system that can be explored by means of modelling and the idea of a radiative theory of climate where not yet conceived. There was no sufficient standardized and developed network of weather stations to observe global effects of the Tambora eruption. Often sensory perception was used for empirical evidence. We conclude from the state of the field regarding the scientific communities and their epistemic means that basic requirements for explaining the YWAS as a climatic fact were missing. Consequently, explaining the YWAS as a climatic factum was not attracting scientists at that time, so that also the last of Fleck's conditions was not fulfilled. But some scientists were ready to take this experiment of nature as an opportunity for reinforcing existing ideas in their domain.

Today, the situation with climate science is completely different. The YWAS has triggered research in climatology, as volcanic eruptions are a relevant topic with regard to seasonal predictability, to geoengineering as well as super eruptions; equally relevant is solar activity (Dalton minimum). Note that today's explanations and reconstructions will potentially be challenged by unexplainable events. This kind of events can trigger interest in learning about the potential and the limits of present-day's scientific ideas. In this regard, interdisciplinary considerations from a science studies' perspective that compare present-day's and historical conceptions can show how scientific innovations are linked with basic shifts in the understanding of a problem. Science studies furthermore show that public interests and popular perceptions also need to be taken into consideration when investigating the development of the scientific understanding of a problem.

\section{Acknowledgments}

We would like to acknowledge funding from the $\mathrm{Cog}$ ito foundation, and from the Department of Environmental Sciences of ETH Zurich, and support from the Swiss National Competence Centre for Research (NCCR) in Climate. We are grateful to Magdalena PORTMANN for providing the content analysis of the Neue Zürcher Zeitung and the Schweizerfreund, to 
Christian PREISWERK for information on the Swiss Natural Sciences Society, to Hartmut Moos for the diary of Johann Peter Hoffman, and to Tracy EWEN for her valuable help with the English.

\section{References}

Aввот, C.G., F.E. Fowle, 1913: Volcanoes and climate. Smithsonian miscellaneous collection 60, 1-24.

Alvarez, L.W., W. Alvarez, F. Asaro, H.V. Michel, 1980: Extraterrestrial Cause for the Cretaceous-Tertiary Extinction. - Science 208, 1095-1108.

BALDWIN, M.P., T.J. DUNKERTON, 2001: Stratospheric Harbingers of anomalous weather regimes. - Science 294, 581-584.

BANKS J., 1817: President of the Royal Society, London, to the Admiralty, Minutes of Council, 20 ${ }^{\text {th }}$ November, 1817. - Royal Society, London 8, 149-153.

BARROW J., 1819: Physikalisch-geografische Nachrichten aus dem nördlichen Polarmeer. - Annal. Physik 62, 157166.

Brandes, H.W., 1817: Aus einem Schreiben des Professor Brandes, meteorologischen Inhalts. - Annal. Physik 55, $112-114$

BRIFFA, K., P. JONES, 1992: The climate of Europe during the 1810 s with special reference to 1816 . - In: Canadian Museum of Nature (Ed.): The Year without a Summer?: World Climate in 1816. Harington C.R., Ottawa.

BriffA K., P. Jones, F. SchWEIngruber, T. OSBORN, 1998: Influence of volcanic eruptions on Northern Hemisphere Summer temperature over the Past 600 Years. - Nature 393, 450-455.

BROHAN, P., C. WARD, G. Willetts, C. Wilkinson, R. Allan, D. WheEler, 2010: Arctic marine climate of the early nineteenth century. - Clim. Past 6, 315-324.

BRÖNNIMANN, S., 1999: Verwildern unsere Alpen? Ein ,nationales Forschungsprojekt" über Klimaänderungen in den Alpen - vor 180 Jahren! - UNIPRESS - Forschung und Wissenschaft an der Universität Bern 101, 17-19.

—, 2002: Picturing climate change. - Climate Res. 22, 87-95.

Chladni, E.F.F., 1819: Ueber die Ursachen des nasskalten Sommers von 1816, und zum Teil auch 1817. - Annal. Physik 62, 132-136.

CRUtzen P.J., 2006: Albedo Enhancement by Stratospheric Sulfur Injections: A Contribution to Resolve a Policy Dilemma? - Climatic Change 77, 211-220.

CRutzen, P.J., J.W. BIRKS, 1982: The atmosphere after a nuclear war: Twilight at noon. - Ambio 11, 114-125.

D'Alembert, JeAn LE Rond: "Climate." The Encyclopedia of Diderot \& d'Alembert Collaborative Translation Project. Translated by Krystyna Piechura. - Ann Arbor: Scholarly Publishing Office of the University of Michigan Library, 2004, http://hdl.handle.net/2027/spo.did2222.0000.267 (accessed October 18, 2010). Originally published as "Climat," Encyclopédie ou Dictionnaire raisonné des sciences, des arts et des métiers 3, 532-534 (Paris, 1753).

DE MARCHI, L. 1895: Le cause dell'era glaciale: ricerca teorica delle condizioni che determinano l'attuale distribuzione delle temperature e delle pioggie sulla superficie terrestre e che possono averla modificata nei precedenti periodi geologici, Tip. Fratelli Fusi, Pavia.

DEFANT, A., 1924: Die Schwankungen der atmosphärischen Zirkulation über dem Nordatlantischen Ozean im 25-jährigen Zeitraum 1881-1905. - Geogr. Ann. 6, 13-41.
DÖRRIES, M., 2006: In the public eye: Volcanology and climate change studies in the 20th century. - Historical Studies in the Physical and Biological Sciences 37, 87-124.

EAST IndiA COMPANy (Ed.), 1816a: The Asiatic Journal and Monthly Register for British India and Dependencies 1, 92-93, 116-17, 125, 177-178, 296-297, 322-24, 372.

- (Ed.), 1816b: Asiatic Journal and Monthly Register for British India and Dependencies 2, 164-166, 421-422.

FLECK, L., 1979 [1935]: Genesis and Development of a Scientific Fact. Trans. by Bradley F, Trenn TJ. - University of Chicago Press, Chicago \& London.

Fleming, J.R., 1998: Historical Perspectives on Climate Change. - Oxford University Press, New York.

, 2007: The Callendar Effect. The Life and Work of Guy Stewart Callendar (1898-1964). The scientist who established the carbon dioxid theory of climate change. - American Meteorological Society, Boston, Mass.

FRANKLIN, B., 1785: 'Meteorological Imaginations and Conjectures. Read December 22, 1784. - Memoirs of the Manchester Literary and Philosophical Society of Manchester 2, 373-377.

GAY-LuSSAC, J.L., F. ARAGO, 1817: Résumé des Observations météorologiques de 1817. - Annales de chimie et de physique 6, 436-444.

Goethe, J.W. von,: Über das Wachstum der Schweizer Gletscher. - In: Die Schriften zur Naturwissenschaft. Erste Abteilung Bd. 11 von GoETHE W. VON, bearb. von Dorothea KUHN und Wolf VON ENGELHARDT, Böhlau Verlag, 1970, Weimar.

GüTlE, J.K., 1820: Beleuchtung eines Aufsatzes über Blitzableiter. - Annal. Physik 64, 262-268.

Hoffmann, J. P.: Auszüge aus dem Tagebuch des Johann Peter Hoffmann (1753-1842), Landwirt und Friedensrichter des Kantons Lützelstein (Elsass), wohnhaft zu Petersbach. - Transkribiert und zusammengestellt von Dieter W. HofFMANN (Privatbesitz von Dieter W. HofFMANN, Uster), gekürzte Fassung von Hartmut MoOs-GOLLNISCH (Kopie bei Stefan BRÖNNIMANN).

HuMPHREYS, W.J., 1913: Volcanic dust and other factors in the production of climatic changes, and their possible relation to ice ages. - Bull. Mount Weather Observatory 6 , $1-34$.

JACKSON, C.I. (Ed.), 2009: The Arctic Whaling Journals of William Scoresby the Younger. Vol. III: The Voyages of 1817, 1818 and 1820. - Hakluyt Society, Third Series 21.

JANkovic, V., 2006: The End of Classical Meteorology, c. 1800. - In: MCCALL, G.J.H., A.J. BOWDEN, R.J. HowARTH (Eds.): The History of Meteoritics and Key Meteorite Collections: Fireballs, Falls and Finds. - Geological Society, London, Special Publications, 91-99.

KRÜGER, T., 2008: Die Entdeckung der Eiszeiten. Schwabe Verlag, Basel.

KUHN, B.F., 1787: Versuch über die Mechanismen der Gletscher. - A Höpfner's Magazin für die Naturkunde Helvetiens $1,119-145$.

LAMB, H.H., 1970: Volcanic dust in the atmosphere: With a chronology and assessment of its meteorological significance. - Royal Society, Series A, Mathematical and Physical Sciences, Philosophical transactions 222, 425-533.

Luterbacher, J., D. Dietrich, E. Xoplaki, M. GrosJEAN, H. WANNER, 2004: European seasonal and annual temperature variability, trends, and extremes since 1500. Science 303, 1499-1503.

MAISSEN, T., 2005: Die Geschichte der NZZ 1780-2005. Verlag Neue Zürcher Zeitung, Zürich. 
Méhay, S., C.E. Keller, S.M. Bernasconi, H. WeisSert, E. ERBA, C. BotTini, P.A. Hochuli, 2009: A volcanic $\mathrm{CO}_{2}$ pulse triggered the Cretaceous Oceanic Anoxic Event 1a and a biocalcification crisis. - Geology 37, 819-822.

Milham, W.I., 1924: The Year 1816, The Cause of Abnormalities. - Mon. Wea. Rev. 52, 563-70.

Mollweide, C.B., 1818: Einige Bemerkungen zu dem Aufsatze des Herrn Moseley über die Sonnenflecken, zur Warnung für ähnliche Täuschungen. - Annal. Physik 58, 426431.

Moseley, W.M., 1818: Bemerkungen über die Sonnenflecken des Jahres 1816. - Annal. Physik 58, 406-416.

NeUE ZürCher ZeItung, 1815-1817. - Orell, Gessner, Füssli \& Co., Zürich.

NiLES, H., 1816: Climate of the United States. - Niles Weekly Register 10, 385-386.

PFISTER, C., 1992: The Years without a Summer in Switzerland: 1628 and 1816. - In: HARINGTON, C.R.: The Year without a Summer? - Canadian Museum of Nature (Ottawa), 416-417.

PFISTER, C., 1999: Wetternachhersage. 500 Jahre Klimavariationen und Naturkatastrophen. - Verlag Paul Haupt, Bern.

Pictet, M.A., 1816: Considerations sur les taches du soleil, et observations de celles qui ont paru l'année dernière et celle-ci. - Bibliothèque universelle, Juillet 1816 Vol 2, No 3, 185-193.

- (Ed.), 1817: Détails sur une éruption volcanique qui a eu lieu dans l'isle de Sumbava. - Bibliotheque Universelle. Sc, et Arts. Nouv. série. Juillet 1817 Vol. 5, No.3, 221-227.

—, 1818: Résume des observations météorologiques. - Bibliothèque universelle Fév. 1818 Vol 2, No7, 83-95.

Roвоск, A., 2000: Volcanic eruptions and climate. - Rev. Geophys. 38, 191-219.

SARASIN, F., P. SARASIN, 1902: Über die mutmassliche Ursache der Eiszeit. - Verhandlungen der Naturforschenden Gesellschaft in Basel Bd. 13, Heft 3, 603-618.

Schaller, N., T. Griesser, A. Fischer, A. StickLER, S. BRÖNNIMANN, 2009: Climate effects of the 1883 Krakatoa eruption: Historical and present perspectives. Vjschr. Natf. Ges. Zürich 154, 31-40.

SHAPIN, F., 2010: Never pure: historical studies of science as if it was produced by people with bodies, situated in time, space, culture, and society, and struggling for credibility and authority. - Johns Hopkins University Press, Baltimore.

SCHWEIZERFREUND, 1815-1817. - Haller, Bern.
Shindell, D.T., G. SChMidt, R.L. Miller, M.E. MANN, 2003: Volcanic and Solar Forcing of Climate Change during the Preindustrial Era. - J. CLimate 16, 4094-4107.

SIEGFRIED, J., 1865: Geschichte der Schweizerischen Naturforschenden Gesellschaft, zur Erinnerung an den Stiftungstag den 6. October 1815 und zur Feier des fünfzigjährigen Jubiläums in Genf am 21., 22. und 23. Augustmonat 1865, herausgegeben von der Schweizerischen Naturforschenden Gesellschaft. - Zürcher und Furrer, Zürich.

Stommel, H., E. Stommel, 1983: Volcano Weather: The Story of 1816, the Year Without a Summer. - Seven Seas Press, Newport.

STOTHERS, R., 1984: The great tambora eruption in 1815 and its aftermath. - Science 224, 1191-1198.

Svensen, H., S. Planke, A.G. Polozov, N. SchmidBAUER, F. CORFU, Y.Y. PODLADCHIKOV, B.R. JAMTVEIT, 2009: Siberian gas venting and the endPermian environmental crisis. - Earth Planetary Sci. Lett. 277, 490-500.

SYMONS, G.J., 1888: The eruption of Krakatoa and subsequent phenomena. - Trübner, London.

TANNER, K.M., 2004: Erinnerungen an "die vielen rothgeweinten Thränen”. - Schweiz. Z. Forstwes. 155, 349-342.

TARAMEllo, T., 1888: Di una vecchia idea sulla causa del clima quaternario. - Rendiconti del Reale Istituto lombardo di scienze e lettere 21, 449-458.

Trigo, R., J. VAquero, M. Alcoforado, M. BArrienDOS, J. TABORDA, R. GARCIA-HERRERA, J. LUTERBACHER, 2009: Iberia in 1816, the year without a summer. - Int. J. Climatol. 29, 99-115.

Turco, R.P., O.B. Toon, T.P. Ackerman, J.B. PolLACK, C. SAGAN, 1983: Nuclear Winter: Global Consequences of Multiple Nuclear Explosions. - Science 222, 1283-1292.

USTERI, P., 1817: Eröffnungsrede der Jahresversammlung der Allgemeinen Schweizerischen Gesellschaft für die gesamten Naturwissenschaften. - Zürich 1817. Auch abgedruckt in: Verhandelungen Schweizerischen Naturforschenden Gesellschaft $\mathrm{Nr}$ 3, 3-59.

VENETZ, I., 1830: Sur l'ancienne extension des glaciers et sur leur retraite dans leur limites actuelles. - Actes de la Société Helvétique des Sciences Naturelles. Quinzième Réunion Annuelle à 1'Hospice du Grand-Saint-Bernard les 21, 22 et 23 juillet 1829, tome 15, 31 .

—, 1833: Les variations de la température dans les Alpes de la Suisse. - Denkschriften (alte Serie), Zürich. Bd. 1, Heft 2, 1-38 